\title{
INFLUENCE OF DRIP IRRIGATION OPERATING AND MANAGEMENT USING SOLAR PHOTOVOLTAIC WATER PUMPING ON STRAWBERRY YIELD INSIDE GREENHOUSES
}

\section{Abu El-Hana,N.H. ${ }^{1}$ M. A. Metwalli $^{2} \quad$ R. M. Abd El-Hameed ${ }^{3^{*}}$ \\ ABSTRACT}

Field experiment was conducted at greenhouses site, Faculty of Agriculture, Kafrelsheikh University during winter season 2014 to study influence of drip irrigation operating and management using solar photovoltaic water pumping on strawberry yield inside greenhouses. The variables were: daily solar radiation $\left(\mathrm{W} / \mathrm{m}^{2}\right)$, emitters discharge $(\mathrm{l} / \mathrm{h})$, controlled greenhouse by (a solar heater, wet pads and fans), uncontrolled greenhouse, temperature $\left({ }^{\circ} \mathrm{C}\right)$ and relative humidity (\%) inside two greenhouses. The main results summarized as follows: The maximum value of the electrical power output, $(117.41 \mathrm{~W})$ and the panel efficiency $(11.62 \%)$ at solar radiation $\left(940 \mathrm{~W} / \mathrm{m}^{2}\right)$. while, the maximum value of the subsystem efficiency and the overall efficiency (45.045 and 5. $64 \%)$ at the minimum value of solar radiation $\left(311 \mathrm{~W} / \mathrm{m}^{2}\right)$ at $13.00 \mathrm{~h}$ during tested days. The distribution uniformity, emitter flow rate variation and manufacturing coefficient of variation were $(72.59,61.5$ and 29.28\%). The results showed the total amount of applied water was 100 and $153.7 \mathrm{l} / \mathrm{m}^{2}$ for plants inside controlled and uncontrolled greenhouse. The obtained mean values of strawberry productivity were ( $42.43,36.55$ , $57.32,61.08$ and $\left.64.97 \mathrm{gm} / \mathrm{m}^{2}\right)$ for controlled greenhouse and ( 18.33 , $20.91,28.38,43.29$ and $48.26 \mathrm{gm} / \mathrm{m}^{2}$ ) for uncontrolled greenhouse from December 2014 to April 2015 respectively.

\footnotetext{
${ }^{1}$ Emeritus Professor, Agric. Eng. Dept., Faculty of Agric., Kafrelsheikh University, 33516, Egypt.

${ }^{2}$ Head Research, Agric. Eng .Res. Institute., A.R.C, Dokki., Giza. Egypt.

${ }^{3}$ Engineer, Agric. Agric. Res. Institute., A.R.C., Dokki., Giza. Egypt.

*For Corresponding : Rofida M. Abd El-Hameed, Email:

rofida.m533@yahoo.com, Tel : +2 01065773566.
} 
The water use efficiency related to the production of total fresh berry yields under controlled and uncontrolled greenhouse, it was $2.62 \mathrm{gm} / \mathrm{l}$ and $1.04 \mathrm{gm} / \mathrm{l}$ respectively.

Keywords: solar photovoltaic, drip irrigation system, solar radiation, greenhouses, Strawberry crop, distribution uniformity, water use efficiency.

\section{INTRODUCTION}



E Energy shortage in Egypt is reaching critical limits that can stop the development efforts on both industrial and agricultural sectors. The use of solar energy is one of the acceptable solutions to address the energy crisis. Pumping water is considered a common need all around the world. Standalone Photovoltices (PV) technologies are being increasingly used for pumping applications. The study has focused on energy and water conserving forms applications drip irrigation for strawberry crop cultivation soilless inside greenhouses. Kruger et al. (1999) said that scheduling water application is very critical to make the most efficient use of drip irrigation system, as excessive irrigation reduces strawberry yields, while inadequate irrigation causes water stress and reduces production. The optimal use of irrigation can be characterized as the supply of sufficient water according to plant needs in the rooting area, and at the same time, avoiding the leaching of nutrients into deeper soil levels.The present study aimed to determine the optimum conditions for production inside greenhouses using photovoltaic cells to pump water for irrigation system. The study aimed also to choose the best management practices of drip irrigation system that are suitable for greenhouses conditions when using a solar powered pumping system. Elham, and Hossen. (2003) mentioned that the study of PV pumping irrigation system in Upper Egypt indicated that the total cost of the PV system was much less than that of diesel system although the initial investment was a little higher than the diesel engine pumping system. Firatoglu and Yesilata. (2004) said that one of the most common applications of photovoltaic systems in developing countries is photovoltaic water pumping which holds the potential of standing out as a significant force for social and economic development. In such a system, there is a direct tie between the amount of water and the availability of solar energy received by the array 
surface. Yuan et al. (2004) studied effects of drip irrigation on the growth and yield of strawberries were studied inside a plastic greenhouse. The amounts of irrigation water applied were $0.75,1.00$ and 1.25 times water surface evaporation (Ep) measured by a standard $200 \mathrm{~mm}$ diameter pan, and the corresponding regimes were denoted Ep 0.75, Ep1.00 and Ep1.25. Irrigated water increased strawberry yields not only by increasing the number of berries, but also by increasing the mean weight of the berries. The trends of the irrigation water use efficiency for the plant biomass and the production of total fresh berry yields showed that the lower the amount of irrigation water received, the higher the irrigation water use efficiency. Based on the experimental results, the optimal amount of irrigation water is about $380 \mathrm{~mm}$, the optimal pan factor is about 1.1 and the optimal irrigation water use efficiency for strawberry yield is about $1.63 \mathrm{gmm}^{-1}$ for strawberry growth and yield inside a plastic greenhouse. So, strawberries grown inside plastic greenhouse should be irrigated using a pan factor of 1.1 as a guideline for irrigation during the full growth seasons. The use of a lower pan factor may reduce the berry yield significantly. Hanson and May. (2007) said that drip irrigation is economizing the available irrigation water. It is also necessary to manage the available water efficiently for maximum crop production. Drip irrigation can apply water both precisely and uniformly at a high irrigation frequency compared with furrow and sprinkler irrigation. Burt and Styles. (2007) mentioned that drip irrigation is a controlled method of irrigation, consisting of tubes with emitters. It allows increasing water use efficiencies by providing precise amounts of water directly to the root zone of individual plants. Gladen.(2009) stated that solar energy is considered a powerful energy source that generates 250 Giga Watts of energy per square kilometer each year which is considered Fair enough if compared to all other renewable energy resources that generate a maximum of $30 \mathrm{GWs} / \mathrm{Km}^{2} /$ year . for these reasons, solar energy in specific can play a great role in providing the world with most of its energy need including electricity, heating and cooling. Zaharim et al. (2009) mentioned that the energy produced by a PV panel can be estimated from the generated power by integrating over the given time. Power produced by the PV panels depends upon the incoming solar 
irradiance and ambient temperature. A long term and accurate data set of net solar irradiance is not available in most parts of the world due to technical, financial, and institutional limitations. Therefore, many studies have been carried out to develop reliable methods and/or models for its estimation. These methods are based on other meteorological variables such as sunshine hours, air temperature, precipitation and air humidity. REN21. (2010) showed that a photovoltaic cell is a solid state device that converts the energy of sun light directly into the electricity using photovoltaic effect. Solar PV generates electricity effectively over 100 countries and continues to be the fastest growing power-generation technology in the world. Between the years 2004 and 2009, gridconnected PV capacity climbed up to an annual average rate of 60 percent. An estimated 7GW of grid-tied capacity was added in 2009, increasing the existing capacity by 53 percent to some $21 \mathrm{GW}$ (off-grid PV accounts for an additional 3-4 GW). Parida et al. (2011) showed that Photovoltaic devices are rugged and simple in design requiring very little maintenance and their biggest advantage being their construction as stand-alone systems to give outputs from microwatts to megawatts. Hence they are used for power source, water pumping, remote buildings, solar home systems, communications, satellites and space vehicles, reverse osmosis plants, and for even megawatt scale power plants. With such a vast array of applications, the demand for photovoltaic is increasing every year. Gao et al.(2013) showed that solar photovoltaic (PV) pumping irrigation system has become a widely applied solar energy technology over the past decades, in which the pump is driven by electricity produced by solar energy and lifts groundwater or surface water to irrigate the crop or grassland for agriculture. They made the benefit analysis for the PV pumping irrigation system. It is concluded that, the PV system has good economic and ecological performance in the demonstration site compared to the diesel engine irrigation system, showing promising prospects to be popularized in Western China at large scale.

\section{MATERIALS AND METHODS}

The field experiment was conducted at Greenhouses site, Faculty of Agriculture, Kafrelsheikh University (latitude $31^{0} 05^{\backslash} 47$ "N, longitude $30^{\circ} 57^{`} 14^{\|} \mathrm{E}$ ) during strawberry cultivation in the period from November 
2014 to April 2015 to test new system of drip irrigation using solar Photovoltaic water pumping on strawberry yield inside controlled and uncontrolled greenhouses .

\section{The Studied Variables}

\section{The experimental studies were confined to determine:}
1. Daily Solar radiation $\left(\mathrm{W} / \mathrm{m}^{2}\right)$.
2. Emitters Discharge $(1 / h)$.

3. Controlled greenhouse by (a solar heater, wet pads and fans) .

4. Uncontrolled greenhouse.

5. Temperature inside Study Greenhouses $\left({ }^{0} \mathrm{C}\right)$.

6. Relative Humidity inside Study Greenhouses (\%) .

\section{On the parameters of study :}

1. The Electrical Power Output of Panel (W) . 2. Panel Efficiency (\%).

3. Subsystem Efficiency (\%). 4. Overall Efficiency (\%).

5. Uniformity Coefficient (\%). 6. Distribution Uniformity (\%).

7. Emitter Flow Rate Variation (\%).

8. Manufacturing Coefficient of Variation (\%).

9. The Amount of Applied Water $\left(1 / \mathrm{m}^{2}\right)$.

10. Crop Productivity $\left(\mathrm{gm} / \mathrm{m}^{2}\right)$.

11. Water Use Efficiency (gm/l).

\section{Photovoltaic System}

The photovoltaic system consists of photovoltaic module, recharging battery, a solar charger, a solar inverter, a time switch and relay.

The PV array has a capacity of 100 peak Watt (1 module) and mounted on an inclined angle of $30^{\circ}$ from the horizontal plane. The PV array has got a tracking arrangement for orienting the panel towards east (from 8.00 to $12.00 \mathrm{hrs}$ ), south (from 12.00 to $14.00 \mathrm{hrs}$ ) and west (from 14.00 to $17.00 \mathrm{hrs}$ ) directions during Winter season.

Recharging Battery $0.660 \mathrm{kWh}$ capacity (charged fully before starting the experiments) was used for storage of power generated by the PV array during day time to meet load requirements at no insolation.

A solar charger Model WS - C2415, it employs solar energy to supply electricity to devices or charge batteries, $(12 \mathrm{~V} \backslash 24 \mathrm{~V}-10 \mathrm{~A})$.

A solar inverter converts the electricity from solar panels (DC, or direct current) into $\mathrm{AC}$ to be used by the plugs for timer. 
A time switch (timer switch) that operates an electric switch controlled by the timing mechanism. The timer turn on loff the water irrigation, It is divided into 24 hours. Each hour is divided into four parts. Each part runs for 15 minutes.

Relay works to connect key or separate power supply. It connects or disconnects the power supply to the circuit high voltage reached through controlled by low voltage circuit, and both circles completely separate from each other.

\section{Drip Irrigation System}

The drip irrigation system consisted of the following components: Submersible pump of D.C. type , 12 V, 10 Amp, outlet diameter of 40 $\mathrm{mm}$, delivery volume of $221 \mathrm{l} / \mathrm{min}$, and delivery head of $10 \mathrm{~m}$. The pump was settled in the well with mainline of $40 \mathrm{~m}$ long and $51 \mathrm{~mm}$ diameter. Sub-mains $26 \mathrm{~mm}$ diameter, lateral lines $16 \mathrm{~mm}$ diameter and Sub-lateral lines $7 \mathrm{~mm}$ diameter with built-in (GR) emitter with $25 \mathrm{~cm}$ spacing between emitters were used. Each lateral line was connected to the submain line through a ball valve. The system was provided with screen filter to prevent emitter clogging that may result from water impurities ,air valve and pressure gauge adjust pressure head and water flow.

\section{Agriculture Methodology inside The greenhouses}

The strawberry crop was cultivated inside two greenhouses its dimensions (30 $\mathrm{m}$ long, $6 \mathrm{~m}$ wide and $3 \mathrm{~m}$ high). The plastic greenhouses was Supported by a steel frame and covered by $0.1 \mathrm{~mm}$ thick white clear polyethylene (PE) film. The first greenhouse environment was controlled by a solar heater which passes heating water inside the greenhouse heating pipes to keep the inside temperature not less than $18{ }^{\circ} \mathrm{C}$ and also it was controlled by cooling system which depended on evaporation of water through wet pads in addition to three ventilating fans to keep the temperature inside the greenhouse not to exceed $26{ }^{\circ} \mathrm{C}$. The crop cultivated in the other greenhouse is directly influenced by the green house environment conditions. Control methods in the environmental conditions inside the greenhouses are considered by using control devices of the control methods latest due to high accuracy in control. 




1. Solar module

5. Relay

9. Screen filter

13. Sub-mains

17. Ball valves
2. Charger

6. The well
3. Battery

7. Submersible Pump 11. Valve

15. Sub-laterals

19. Agriculture slot
4. Inverter and Timer

8. Air Valve

12. Mains

16. Emitters

Fig. 1. Schematic diagram of solar photovoltaic powered drip irrigation system The control device consists of microcomputer, the unit data conversion which receives the data from the sense devices for the environmental conditions, computer screen to present the data and printing strips to store the data. The followed Control way is : the various sense devices send vibrations positive to the unit of recording data that Converts the data to a digital waves and send data to control device that compares the received data with Stored and programmed values for control . If these data more or less than the stored values, the control device Sends the information to the control circuits to $\mathrm{ON}$ or OFF the various control devices ( Cooling System Heating System and fans ) to access environmental conditions as they are stored in the control device. 




Fig. 2. Schematic drawing study greenhouses

\section{Energy, Water and Crop Parameters}

\section{Input and output power to the System}

The insolation to the PV array gives the input power $\left(\mathrm{P}_{\text {in }}\right)$ to the system was calculated by using (Hamza and Taha equation, 1995):

$$
\begin{array}{ll}
P_{\text {in }}=\text { Ins x a } & , W \\
P_{\text {output }}=V_{o c} \times I_{s c} & , W
\end{array}
$$

\section{Where:}

$$
\begin{array}{rlrl}
\text { Ins } & =\text { insolation, } \mathrm{W} / \mathrm{m}^{2} & \mathrm{a}=\text { solar module area, } \mathrm{m}^{2} \\
\mathrm{~V}_{\mathrm{oc}} & =\text { open circuit voltage, } \mathrm{V} & & \mathrm{I}_{\mathrm{sc}}=\text { short circuit current, } \mathrm{A}
\end{array}
$$

\section{PV panel efficiency}

PV panel efficiency $\left(\eta_{\text {panel }}\right)$ is the measure of how efficient the PV panel is in converting sunlight to electricity. PV panel efficiency was calculated by using the following equation:

$$
\eta_{\text {panel }}=\frac{P_{\max }}{P_{\text {in }}}=\frac{V_{\mathrm{OC}} \times I_{S C} \times F F}{\operatorname{Ins} \times a} \times 100
$$


Where: $\quad \mathrm{FF}=$ fill factor which equals about 0.67 for $\mathrm{Si}$.

\section{Subsystem efficiency}

Subsystem efficiency $\left(\eta_{\mathrm{s}}\right)$ is the efficiency of the entire system components. It was calculated by using the following equation:

$$
\eta_{\mathrm{s}}=\left(\mathrm{P}_{\mathrm{h}} / \mathrm{P}_{\text {outp }}(\mathrm{H}) \mathrm{x}\right) \mathrm{X} 100, \%
$$

\section{Overall efficiency}

Overall efficiency $\left(\eta_{\text {overall }}\right)$ indicates how efficiently the overall system converts insolation into water delivery at a given head. It was calculated by using the following equations:

$$
\begin{aligned}
& \eta_{\text {overall }}=\left(P_{h} / P_{\text {in }}\right) \times 100 \% \\
& \eta_{\text {overall }}=\eta_{\text {panel }} \times \eta_{s}
\end{aligned}
$$

\section{Manufacturing coefficient of variation}

The manufacturer variation is actually caused by the non-uniform production from the manufacturer. Manufacturer coefficient of variation was calculated by using the following equation according to (ASAE1991).

$$
C V=S / q^{\backslash} \times 100
$$

\section{Where:}

$\mathrm{CV}=$ manufacturing coefficient of variation, $\%$.

$\mathrm{S}=$ standard deviation of emitters flow rate, $1 / \mathrm{h}$.

$\mathrm{q}^{\prime}=$ average of emitter flow rate, $1 / \mathrm{h}$.

\section{Uniformity coefficient}

The degree of emitter flow variation is expressed by the uniformity coefficient. To measure the degree of water distribution uniformity from the drip irrigation system on the irrigated area must be found uniformity coefficient. The coefficient is calculated from field measurements for the depths of the collected water in measurement containers that is placed under each emitter. And to find uniformity coefficient is used vessels had equal volumes along the drip line and is found coefficient of equation No. 10. Uniformity coefficient was calculated by using the following equation according to (Christiansen, 1942).

$$
U C=100\left[1-\frac{\frac{1}{\mathrm{n}} \sum_{i=1}^{n}\left|q_{i}-\bar{q}\right|}{\bar{q}}\right]
$$




\section{Where:}

$\mathrm{UC}=$ uniformity coefficient, \%. $\mathrm{n}=$ number of observed emitter or cans.

$\mathrm{q}_{\mathrm{i}}=$ emitter flow rate, $1 / \mathrm{h} . \quad \mathrm{q}^{\prime}=$ average of emitters flow rates, $1 / \mathrm{h}$.

\section{Distribution uniformity}

Distribution uniformity was calculated by using the following equation (Kruse, 1978) :

$$
D U=100 \frac{\bar{q}_{1 q}}{q}
$$

\section{Where:}

DU $=$ distribution uniformity, $\%$.

$q^{\prime}=$ average of emitters flow rates, $1 / \mathrm{h}$.

$\mathrm{q}_{\mathrm{iq}}^{\prime}=$ mean of lowest one-fourth of emitter flow rates, $1 / \mathrm{h}$.

\section{Emitter flow rate variation}

The following equation was used to collect the emitter flow rate variation according to $(\mathbf{W u}, \mathbf{1 9 9 2})$ :

$$
q_{v a r}=\frac{q_{\max }-q_{\min }}{q_{\max }}
$$

\section{Where:}

$\mathrm{q}_{\max }=$ maximum emitter flow rate, $1 / \mathrm{h}$.

$\mathrm{q}_{\min }=$ minimum emitter flow rate, $1 / \mathrm{h}$.

\section{Gross irrigation requirements}

The gross irrigation requirements were calculated by using the following equation referring to (FAO, 1980).

$$
\begin{gathered}
I R_{g}=\frac{\boldsymbol{I R}_{\boldsymbol{n}}}{\boldsymbol{E}_{\boldsymbol{i}}} \\
I R_{n}=E T_{\text {crop }}+L r
\end{gathered}
$$

Where:

$\mathrm{IR}_{\mathrm{n}}=$ net irrigation requirements, $\mathrm{mm} /$ day .

$\mathrm{IR}_{\mathrm{g}}=$ gross irrigation requirements, $\mathrm{mm} /$ day.

$\mathrm{E}_{\mathrm{i}}=$ irrigation system efficiency (assumed $80 \%$ for drip irrigation system). 
$\mathrm{Lr}=$ leaching requirements, $\mathrm{mm} / \mathrm{day}$. (neglected depending on quality specifications of irrigation water .

$\mathrm{ET}_{\text {crop }}=$ crop water requirements, $\mathrm{mm} /$ day. Which was calculated by using the following equation (FAO,1980) .

$$
E T_{\text {crop }}=K c . K r . E T_{0}
$$

\section{Where:}

$\mathrm{K}_{\mathrm{c}}=$ crop factor $(0.40,0.85$ and 0.75 for the first , second and last third of growing season, respectively according to (FAO 1998)). $\mathrm{K}_{\mathrm{r}}=$ reduction factor (space between plants $\mathrm{x}$ space between laterals / 0.85 or 1 which is least (Keller and Karmeli,1975).

$\mathrm{Et}_{\mathrm{o}}=$ reference of evapotranspiration, $\mathrm{mm} /$ day.

\section{Water use efficiency}

Water use efficiency has been used to show the relation between Strawberry crop production and the total amount of water used. It was determined by using the following equation (Jensen, 1983):

$$
W U E=\frac{\boldsymbol{Y}}{\boldsymbol{W}_{\boldsymbol{a}}}
$$

Where:

WUE $=$ Water use efficiency, $\mathrm{kg} / \mathrm{m}^{3} \quad \mathrm{Y}=$ total yield, $\mathrm{kg} / \mathrm{fed}$.

$\mathrm{W}_{\mathrm{a}}=$ total applied water, $\mathrm{m}^{3} /$ fed.

\section{Irrigation system costs}

\section{Fixed costs}

Annual depreciation: It was calculated for (panel , pump, battery and irrigation network components) as follows:

Annual depreciation $=$ prime machine price-price at the end of expected operating life

expected life,year

Price of the machine at the end of operating life was assumed as $10 \%$ of the main price.

Interest and investment: Interest ratio was assumed $12 \%$. The following formula was used to calculate interest costs according to (El-Dnasoury, 2001).

Interest costs $=$

Interest ratio $\frac{\text { Main price + price at the end of life }}{2}$ 
Taxes, insurance and shelter : It was assumed to be $2 \%$ of the main machine price (El-Dnasoury, 2001).

\section{Variable costs}

Repairs and maintenance: It was assumed to be $100 \%$ of annual depreciation cost (El-Dnasoury, 2001).

Labor cost: The operator salary about 5 L.E/h.

Fuel consumption L.E/h, lubrication costs for a machine are equal to 10 $\%$ of fuel cost .

\section{RESULTS AND DISCUSSION \\ 1.Performance of solar photovoltaic system}

\section{a. The electrical power output of solar module and panel efficiency}

The average daily solar radiation measured on the module surface for sunny day from 8 to17 hrs. The measured data indicated that higher solar radiation was observed before noon in comparison to that in the afternoon. When the panel faced southward the sun rays were perpendicular to the array, resulting in increased solar radiation values, which peaked at $13.00 \mathrm{~h}$. This result is corresponding to $20{ }^{\circ} \mathrm{C}$ and $35{ }^{\circ} \mathrm{C}$ for ambient temperature and panel temperature. The electrical power output was measured for typical clear sunny days in winter 2014-2015. The analysis of measured data indicated that the power output of solar module changed highly significantly with solar radiation during winter season which may be due to increase of clearness index. Fig. 3 shows the variation of power output, $\mathrm{P}_{\text {output }}$, of solar module and conversion efficiency as affected by solar radiation with respect to zonal time of the day. The maximum $\mathrm{P}_{\text {output }}$ were measured at $13.00 \mathrm{~h}$ during tested days. The reason for that may be due to, the generated short circuit current, Isc, which increased more than the drop in voltage at noon.

Also, the higher $\mathrm{P}_{\text {output }}$ at morning was observed in comparison to those in the evening, this may be due to the module heating up in the afternoon more than mornings. It is observed that the average value of $p_{\text {output }}$ which is minimum $(23.4 \mathrm{~W})$ at irradiation, $311 \mathrm{~W} / \mathrm{m}^{2}$ and it is maximum $(117.41 \mathrm{~W})$ at solar radiation, $940 \mathrm{~W} / \mathrm{m}^{2}$, the average value of panel efficiency which is minimum $(7.00 \%)$ at irradiation, $311 \mathrm{~W} / \mathrm{m}^{2}$ and it is maximum $(11.62 \%)$ at solar radiation $940 \mathrm{~W} / \mathrm{m}^{2}$. So it can be said $\mathrm{P}_{\text {output }}$ and $\eta_{\text {efficiency }}$ is rising up with increasing solar irradiation. 




Fig. 3. The Relation between solar radiation, the electrical power output and panel efficiency

\section{b. Subsystem efficiency and overall efficiency}

From figures 4 and 5, it is evident that the subsystem efficiency and the overall efficiency have the same trend. They both increase from no discharge to reach the beak at the critical solar radiation, then they reduce with the increase in solar radiation. Fig. 4 shows that the subsystem efficiency increases to reach the peak $(45.045 \%)$ at irradiation, $311 \mathrm{~W} / \mathrm{m}^{2}$ and it reduces $(10.77 \%)$ at irradiation, $940 \mathrm{~W} / \mathrm{m}^{2}$. Fig. 5 shows that the overall efficiency increases to reach the peak $(5.64 \%)$ at irradiation, $311 \mathrm{~W} / \mathrm{m}^{2}$ and it reduces $(1.86 \%)$ at irradiation, $940 \mathrm{~W} / \mathrm{m}^{2}$.

\section{Emitter Performance}

Fig. 6. Shows the measured drippers discharge during the operating of drip irrigation system during the field evaluation. Of this curve it can be said that there is a clear difference in drippers discharge on the drip line for system. where, drippers discharge was $(2.32,1.72,2.04,1.2,2.6$, $1.08,1.52,1.32,1.6,2.2,1.46,1.88,1.4,2.1,1.13$ and $11 / \mathrm{h}$ ) for drippers $(4,8,12,16,20,24,28,32,36,40,44,48,52,56,60$ and 64$)$ respectively. 




Fig. 4. Subsystem efficiency of PV pumping system versus solar radiation.



Fig. 5. Overall efficiency of PV pumping system versus solar radiation



Fig. 6. Measured emitters discharge along the drip line

Fig.7. shows the results of the evaluation uniformity coefficient and it found that there is a variation from emitter to other along the drip line. where it was $(97.52,99.77,98.57,98.27,96.46,97.82,99.47,98.72$, 
$99.77,97.97,99.25,99.17,99,98.34,98$ and $97.52 \%)$ for drippers (4, $8,12,16,20,24,28,32,36,40,44,48,52,56,60$ and 64 ) respectively. as well as it can be said that there are degrees of variation in the manufacturing and maintenance of those drippers. Distribution uniformity was calculated from equation No.9. It found that DU $=72.59 \%$, Emitter flow rate variation was calculated from equation No.10. It found that $\mathrm{q}_{\mathrm{var}}$ $=61.5 \%$ and Manufacturing coefficient of variation was calculated from equation No.7. It was $29.28 \%$. So it can be said that there are variation in the distribution of water. so ,it must be considered in manufacturing, management and maintenance of emitters.

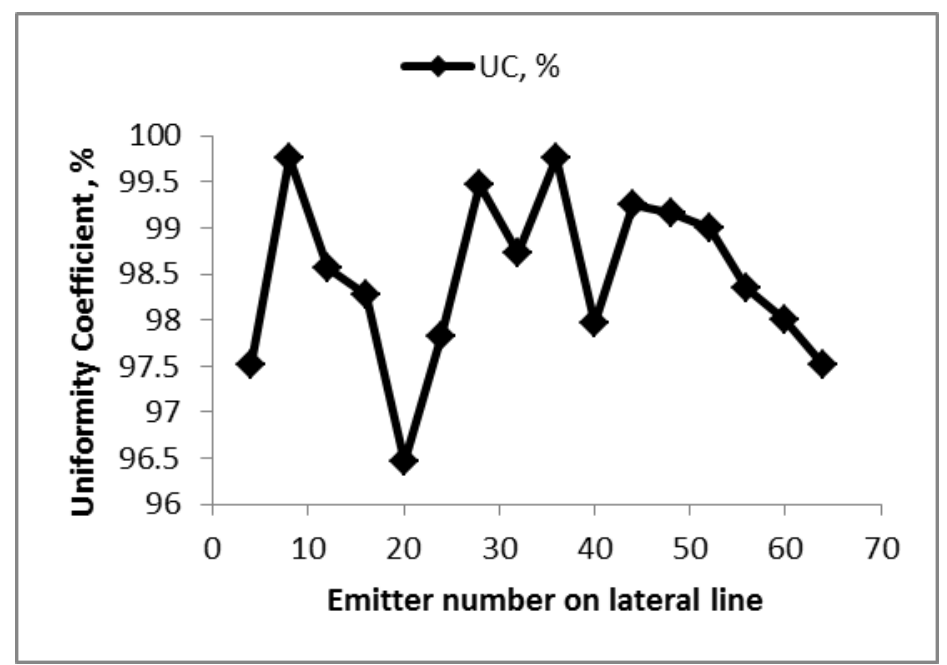

Fig.7. Uniformity coefficient for selected emitters

\section{Strawberry yield (growth)}

Temperature is considered the most important weather factors impact on the growth and production of strawberry crop. Where, the crop has appropriate extent of temperature growths of it. Fig .8 shows temperature difference inside study greenhouses controlled and uncontrolled. Temperature average was $\left(29,28.2,26.31,27.5,30.49\right.$ and $33.41{ }^{\circ} \mathrm{C}$ inside uncontrolled greenhouse. While, it was $(21.8,22.7,20.3,22$, 23.28 and $25{ }^{0} \mathrm{C}$ ) inside controlled greenhouse respectively from November 2014 to April 2015. It increased inside uncontrolled greenhouse on permissible limit, which affected negativity on the vegetative and Syphilis growth and thus the productivity of the crop. 
While, inside controlled greenhouse and with control in system ventilation and heating led to reach the desired temperature for crop strawberry growth and increase of the crop productivity. Humidity effects on the speed of biological processes in the plant because of its impact on the rate of transpiration .where, the increase of humidity lead to reduce the transpiration rate of the plant and Perhaps plant absorbs water droplets from the air through the stomata and thus increases the water content of inner plant. And must be taken not to increase the moisture on optimal, as an increase in humidity can cause some damage to plants, and lead to the spread of fungal and bacterial diseases. Fig.9 shows relative humidity inside study greenhouses, it is observed low humidity inside uncontrolled greenhouse on permissible limit which was $(60.34,64.8$, 68.7, 66.53, 58.71 and $55.17 \%$ ) respectively from November 2014 to April 2015. Be a direct effect of the lack of moisture as a result of increased lost water from the absorbed water, which led to an imbalance in the balance water, which in turn led to the small size of plant and a decrease in photosynthesis as a result of the closure of the stomata and the occurrence loss of flowers and modern decade and leading to low of the crop quality. While, inside controlled greenhouse with use of control systems the moisture was $(74.15,78.5,84.6,80.2,72.59$ and $70.41 \%)$ respectively from November 2014 to April 2015. It is noted plants growth well inside controlled greenhouse because of lack of transpiration which led to access irrigation water the plants with the amount that needed without wasting water which led to high of the crop quality and productivity.

\section{Water relations}

\section{a. Applied water}

Fig.10 shows the amount of applied water inside study greenhouses during the agriculture season. It is evident that the maximum of applied water for plants inside controlled and uncontrolled greenhouse respectively, 31 and $40.3 \mathrm{l} / \mathrm{m}^{2}$ in April. While, the minimum of applied water for plants inside controlled and uncontrolled greenhouse respectively, 5.6 and $14 \mathrm{l} / \mathrm{m}^{2}$ in January. The results showed the total amount of applied water was $100 \mathrm{l} / \mathrm{m}^{2}$ for plants inside controlled greenhouse. While, the total amount of applied water was $153.7 \mathrm{l} / \mathrm{m}^{2}$ for 
plants inside uncontrolled greenhouse. This difference in the amount of applied water inside the two greenhouses due to the increase of temperature significantly on permissible limit and decrease humidity inside uncontrolled greenhouse that lead to increased lost water from the absorbed water and therefore plants need to a large quantities of irrigation water to compensate losses. While, plant growth at suitable temperature and humidity, it can maintain the amount of water and thus decrease the amount of applied water that the plant needed due to lack of transpiration.



Fig.8. Temperature difference inside study greenhouses for months



Fig.9. Relative humidity inside study greenhouses for months 




Fig. 10. Applied water for plants inside study greenhouses for months

\section{b. Crop productivity}

Fig.11 shows the dynamic changes in cumulated strawberry fruit yield inside study greenhouses. There was a significant increase in total berry production as the amount of irrigation water increased during the planting season. Greater the amount of irrigation water, the larger the berry yield. The increase in the amount of irrigation water also produced larger berry weight. Irrigated water increased strawberry yields not only by increasing the number of berries, but also by increasing the mean weight of the berries. In general, irrigation increased total season fruit yields, marketable yields and the number of berries.

The obtained mean values of strawberry productivity were $42.43,36.55$, $57.32,61.08$ and $64.97 \mathrm{gm} / \mathrm{m}^{2}$ for controlled greenhouse and they were $18.33,20.91,28.38,43.29$ and $48.26 \mathrm{gm} / \mathrm{m}^{2}$ for uncontrolled greenhouse from December 2014 to April 2015 respectively. It can be noted that the productivity decreased in uncontrolled greenhouse compared with controlled greenhouse because increased of temperature and humidity decreased that led to increased transpiration and then weakness and damage of fruits and low productivity. The results also show that the temperature and humidity are essential factors to the success of the strawberry cultivation, so it is recommended to use the 
controlled greenhouse to cultivate strawberry crop and so can be adjusted suitable temperature and humidity for the cultivation of the crop and then provide the amount of irrigation water.

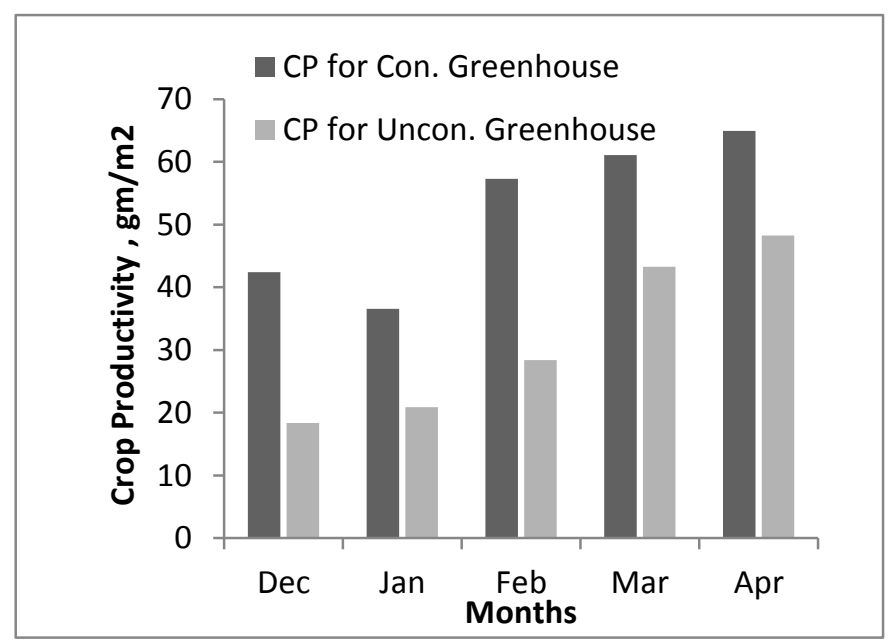

Fig. 11. Crop productivity inside study greenhouses for months

\section{c. Water use efficiency}

From the obtained results, there were various production concerned with the total amount of applied irrigation water relative to berry yield. Irrigation water use efficiency (IWUE) is the relation between yield and the quantity of irrigation water. The WUE related to the production of total fresh berry yields under controlled and uncontrolled greenhouse, it was $2.62 \mathrm{gm} / 1$ and $1.04 \mathrm{gm} / 1$ respectively. In general, the trend for the WUE for the production of total fresh berry yields showed that the lower the amount of irrigation water received, higher the irrigation water use efficiency within the threshold of applied irrigation water.

\section{Cost estimation}

The expectancy life of materials was $20,6,14,10,10,10,10,10$ and 10 years for Panel ,Battery ,Pump, mains , sub-mains, laterals, Sub-laterals, valves and controls respectively.The price of mains, sub-mains, laterals, Sub-laterals, valves and controls was taken as zero at the end of the expectancy life. The cost of operating hours was determined considering 20, 6, 14 and 10 years expectancy life of Panel , Battery , Pump and 
Irrigation Network Components respectively . It could work about 600 hours every year. In addition to the operator salary about 5.00 L.E/h for labor .The lowest value of the cost of operating Panel, Battery, Pump and Irrigation network Components for one hour was 5.218, 0.177, 0.137 and $8.575 \mathrm{~L} . \mathrm{E} / \mathrm{h}$ respectively . The economic analysis proved that the PV powered pump is preferable in the long run. The fuel prices are too high in Egypt which has a negative effect on diesel water pumping system in the long run.

11-Operating Costs (L.E / Year) of Panel, Battery, Pump and Irrigation network Components $=14.107$ L.E/ Hour

12-Total Costs $($ L.E $/$ Year $)=$ Fixed Costs + Operating Costs $=8465.09$

L.E/Season

\section{CONCLUSION}

It is recommended to use solar cells to pump irrigation water for drip irrigation system to obtain a higher efficiency of water use. It is also recommended to use controlled greenhouses to cultivate strawberry crop to reach higher productivity and quality.

\section{REFERENCES}

ASAE.1991. Design and installation of microirrigation systems.ASAE Engineering . practice. ASAE.EP 4051.

Burt, C.M., and S. W. Styles. 2007. Drip and Micro Irrigation Design and Management for Trees, Vines, and Field Crops. 3rd Edition. Irrigation Training and Research Center.

Christiansen, J. E. 1942. Hydraulics of sprinkling systems for irrigation. Trans. Amer. Soc. Civ. Eng. 107:221-239.

Elham, M., and E, Hossen. 2003. Renewable energy and sustainable. Developments in Egypt: photovoltaic water pumping in remote areas. Appl Energy.74:141-7.

FAO.1980. Irrigation and Drainage. Paper No.36 . Localized. Irrigation. Rome. 
FA0.1998. Crop Evapotranspiration - Guidelines for computing crop water requirements -FAO Irrigation and drainage. paper No.56.

Firatoglu, Z.A. and B. Yesilata. 2004. New approaches on the optimization of directly. couple PV pumping systems. Solar Energy $77,81-93$.

Gao, X., J. Liu., Zhang . J., Yan. J., Bao. S ., Xu. H., and T. Qin. 2013. Feasibility . evaluation of . solar photovoltaic pumping irrigation system based on analysis. of dynamic variation of groundwater table.Applied Energy105 (2013) . 182- 193.

Gladen, H.2009. Solar Thermal Power Plants Firm Capacity with $100 \%$ Renewable. CUEN $3^{\text {rd }}$ Annual Energy Conference. Solar Millennium AG. Retrieved on 19 March fromwww.cuen.org.uk/img/Academic_Material/Glagen.pdf

Grant,O.M., W.J..Abigail., M.J.Davies., C.M.James.,and D.W. Simpson. 2010. Physiological and morphlogical diversity of cultivated. strawberry (Fragaria $\mathrm{x}$ a nanassa) in response to water. deficit. Environmental and Experimental. Botany 68, 264-272.

Hamza, A. A., and A. Z. Taha. 1995. Performance of submersible PV solar pumping system under conditions in the Sudan Renewable Energy 6(5): 491-495.

Hanson, B., and D. May. 2007. The Effect of drip line placement on yield and quality. drip- irrigated processing Tomatoes. Irrigation and Drainage System. (21): 109-118.

Jensen, M.E.1983.Design and operation of farm irrigation systems. ASAE, Michigan, USA.p827.

Kruger.E.,G .Schmidt., and U. Bruckner 1999. Scheduling strawberry irrigation. based upon tensiometer measurement and a climatic water balance model. Scientia . Horticulturae, 81, 409-424 .

Kruse, E. G. 1978. Describing irrigation efficiency and uniformity. J. Irrig. Drain. Div. ASCE 104(IR):35-41. 
Parida. B., S. Iniyan.,and R .Goic. 2011. A review of solar photovoltaic technologies Renewable and Sustainable Energy Reviews 15: $1625-1636$.

REN21. 2010. Renewable energy Policy Network for the 21st Century Renewables 2010 Global Status Report (Paris: REN21 Secretariat).

Wu, I. P. 1992. Energy gradient line approach for direct calculation in drip irrigation. design.Irrig. Sci. 13:21-29.

Yuan, B.Z.; J. Sun; and S. Nishiyama . 2004. Effect of Drip Irrigation on Strawberry . Growth and Yield inside a Plastic Greenhouse. Biosystems Engineering 87 . (2), 237-245.

Zaharim, A., A.M. Razali., T.P. Gim., and K. Sopian. 2009 . Time series analysis of solar radiation data in the tropics. European. Journal of Scientific Research. Vol. 2(4): 672-678.

ثانيا : المراجع العربية

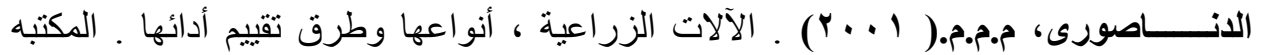



\section{الملخص العزبي}

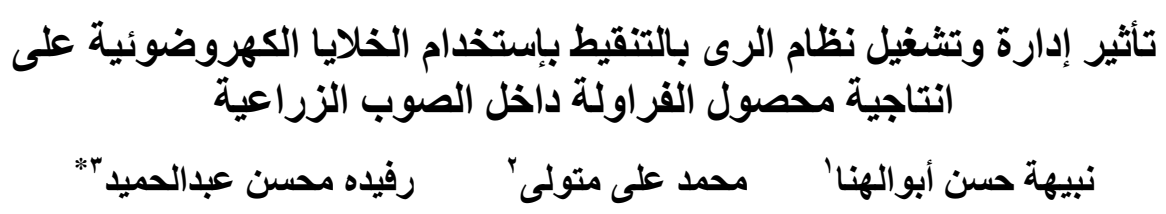

تعتبر أزمة نقص الطاقة من المشكلات الأساسية التى تواجة مصر فى الآونة الأخيرة و التى قد

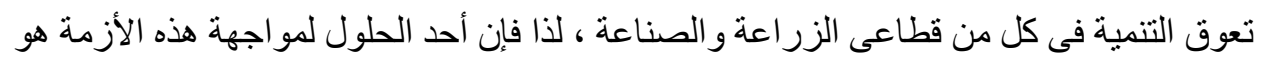

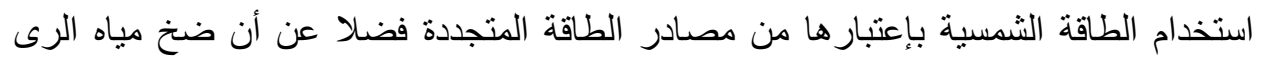

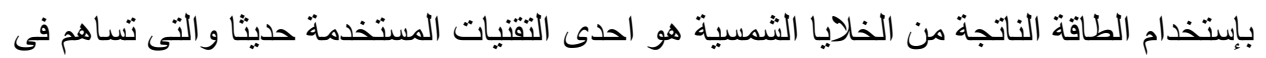
تقليل عجز الطاقة.

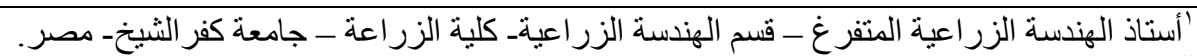

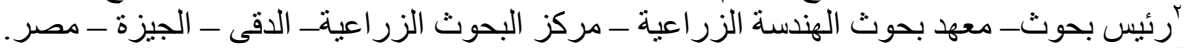

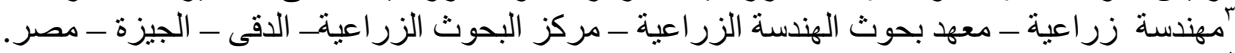

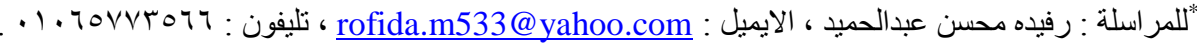




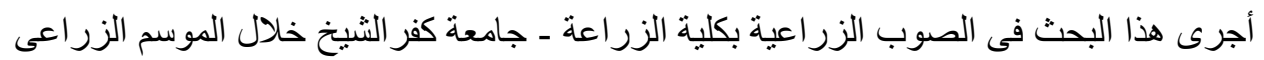

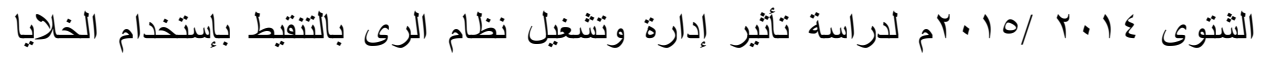
الكهروضوئية على انتاجية محصول الفراولة وكفاءات الرى داخل داخل الصوب الزبر الزية اعية. وشملت الار اسة المتغيرات الآتيه : الآنيه

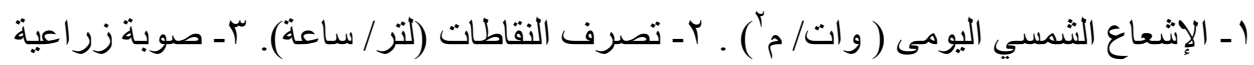

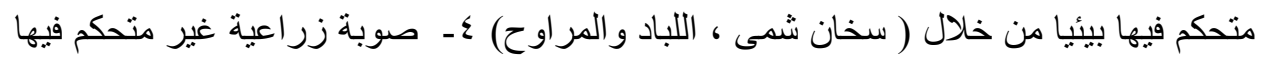

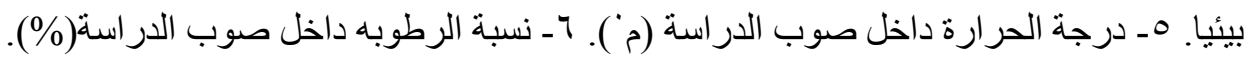

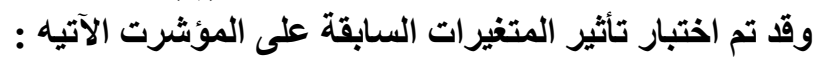

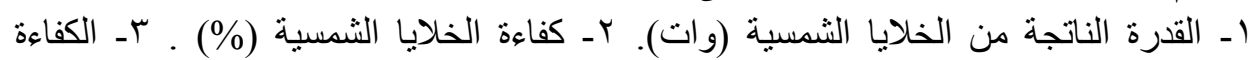

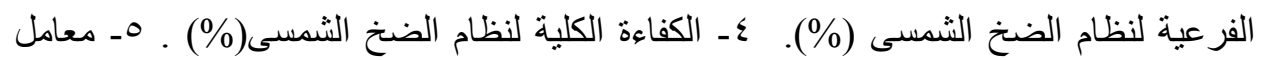

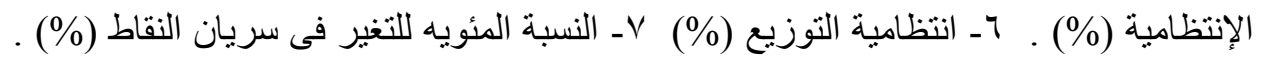

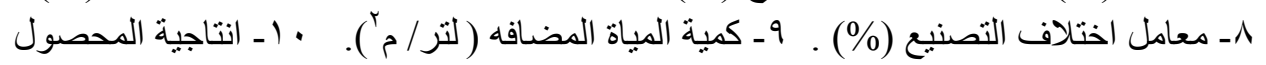

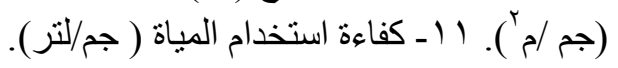

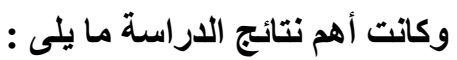

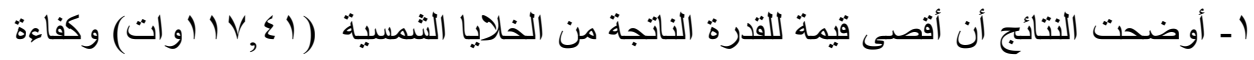

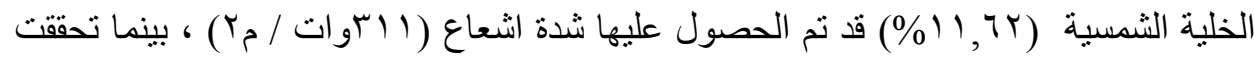

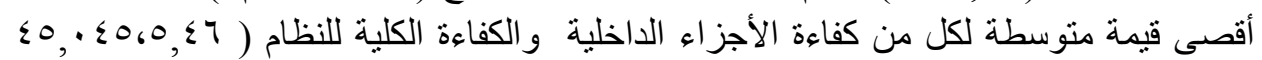

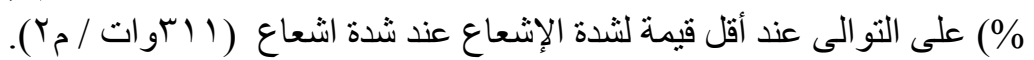

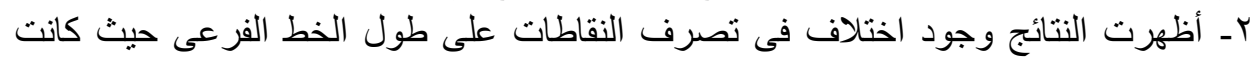

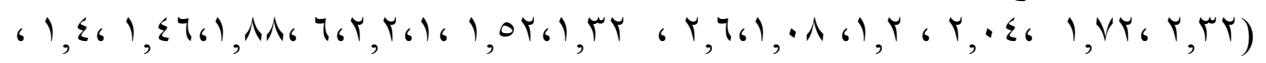

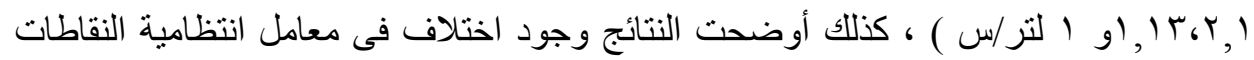

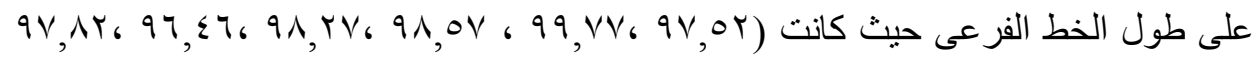

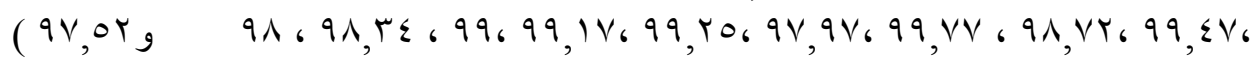
للنقاطات (

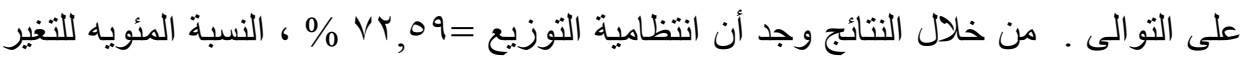

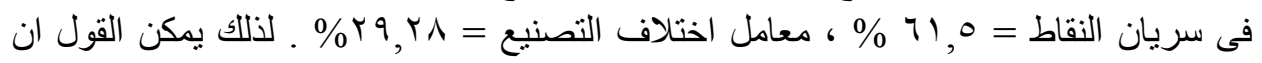
هناك تفاوت فى درجات الصيانه و الادر اة لتلك المنقطات.

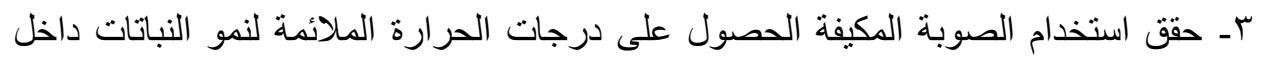

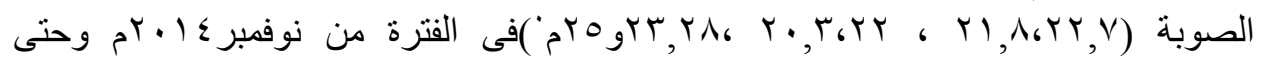

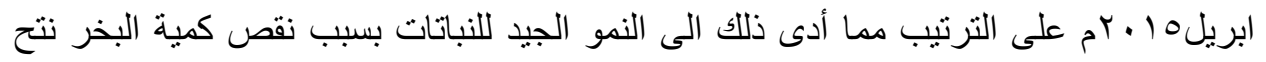
و عدم وجود فقد فى المياه ومن ثم الحصول على أعلى انتاجية للمحصول مقارنة بالصوبة الغير مكيفة.

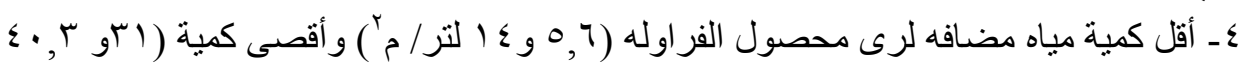

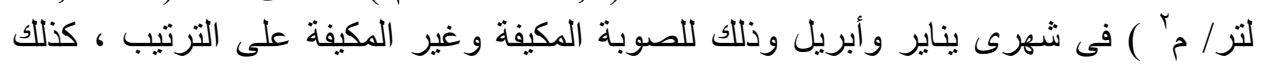


أظهرت النتائج القيمة الكلية لكمية المياة المضافه للنباتات خلال موسم النمو داخل الصوبه المكيفة

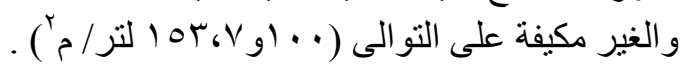

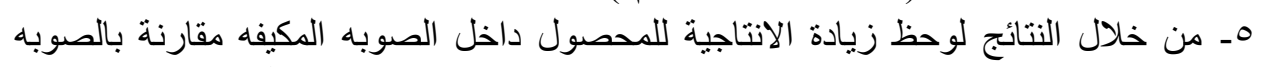
المكيفه حيث كانت (Tr,

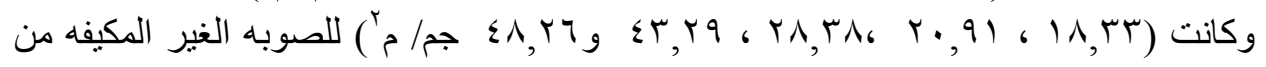

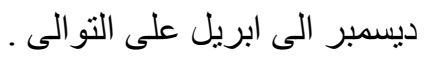

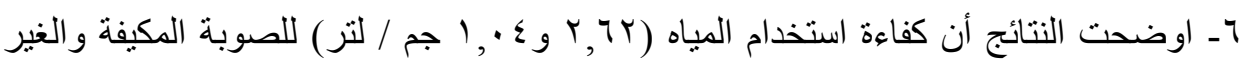

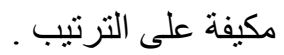
V- توصى الدر اسة بإستخدام الخلايا الثمسية لضخ مياه الرى بالتنقيط للحصول على أعلى كفاءة

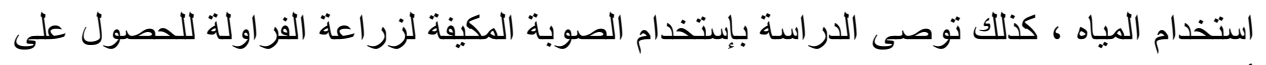

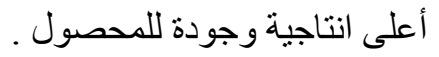

